\title{
Pengaruh Pupuk Hayati Majemuk Cair dan Pupuk Sintetik Terhadap Pertumbuhan Tanaman Edamame (Glycine max (L.) Merr)
}

\author{
L. Fahmi ${ }^{a}$, A. Rahayu ${ }^{b}$ dan Y. Mulyaningsih ${ }^{b}$ \\ ${ }^{a}$ Mahasiswa S1 Program Studi Agroteknologi, Fakultas Pertanian, UNIDA \\ ${ }^{\mathrm{b}}$ Staf Pengajar Program Studi Agroteknologi, Fakultas Pertanian, UNIDA
}

\begin{abstract}
Abstrak
Salah satu cara meningkatkan produktivitas tanaman edamame adalah dengan pemberian pupuk. Budidaya edamame saat ini umumnya menggunakan pupuk sintetik, penggunaan pupuk sintetik yang berlebih dapat mengurangi kesuburan tanah sehingga perlu disubtitusi dengan pupuk hayati. Penelitian ini bertujuan untuk mengetahui pengaruh pemberian pupuk hayati dan pupuk sintetik terhadap pertumbuhan dan produksi tanaman edamame. Penelitian ini dilakukan dengan Rancangan Acak Lengkap pola faktorial. Faktor pertama adalah dosis pupuk hayati terdiri atas tiga taraf yaitu tanpa pupuk hayati $(0 \% \mathrm{R}), 5 \mathrm{ml} / \mathrm{l}(50 \% \mathrm{R}), 10 \mathrm{ml} / \mathrm{l}(100 \% \mathrm{R})$. Pupuk sintetik yang diberikan terdiri atas lima taraf yaitu tanpa pupuk buatan $(0 \% \mathrm{R})$, pupuk sintetik $25 \%$ dari rekomendasi (Urea 37,5 kg/ha, SP-36 37,5 kg/ha, KCl $25 \mathrm{~kg} / \mathrm{ha}$ ), pupuk sintetik 50\% dari rekomendasi (Urea $75 \mathrm{~kg} / \mathrm{ha}$, SP-36 $75 \mathrm{~kg} / \mathrm{ha}, \mathrm{KCl} 50 \mathrm{~kg} / \mathrm{ha}$ ), pupuk sinetik $75 \%$ dari rekomendasi (Urea 112,5 kg/ha, SP-36 112,5 kg/ha, KCl $75 \mathrm{~kg} / \mathrm{ha}$ ), dan pupuk sintetik 100\% dari rekomendasi (Urea $150 \mathrm{~kg} / \mathrm{ha}$, SP-36 $150 \mathrm{~kg} / \mathrm{ha}, \mathrm{KCl} 100 \mathrm{~kg} / \mathrm{ha}$ ).

Hasil penelitian menunjukan tanaman yang diberi pupuk hayati dengan dosis $100 \%$ rekomendasi nyata lebih tinggi dan lebih banyak jumlah daun pada 5 MST serta berbeda nyata terhadap bobot basah dan kering akar. Pupuk sintetik dengan dosis 100\% rekomendasi berbeda nyata terhadap tinggi tanaman, jumlah cabang, jumlah daun, dan jumlah bunga pada 5 MST, serta berbeda nyata terhadap bobot basah akar, dan bobot kering akar. Interaksi antara pupuk hayati $100 \%$ rekomendasi dengan pupuk sintetik $100 \%$ rekomendasi berbeda nyata terhadap jumlah daun dan jumlah bunga.
\end{abstract}

Kata kunci: Tanaman edamame, pupuk hayati, pupuk sintetik

\section{Abstract}

Fertilizer administration is a way to increase the productivity of edamame plants. Synthetic fertilizer is commonly used in edamame cultivation today. However, excessive use of synthetic fertilizer could reduce soil fertility so that substitution of it with biofertilizer is needed. This study was aimed at assessing the effects of biofertilizer and synthetic fertilizer administration on the growth and production of edamame plants. A completely randomized design in a factorial pattern was used. The first factor was biofertilizer rates consisting of three levels namely no fertilizer $(0 \% \mathrm{R}), 5 \mathrm{ml} / \mathrm{l}(50 \% \mathrm{R})$, and $10 \mathrm{ml} / \mathrm{l}(100 \% \mathrm{R})$. synthetic fertilizer was given in five levels consisting of no fertilizer ( $0 \% \mathrm{R}), 25 \%$ recommended rate (urea $37.5 \mathrm{~kg} / \mathrm{ha}$, SP-36 37.5 $\mathrm{kg} / \mathrm{ha}$, and $\mathrm{KCl} 25 \mathrm{~kg} / \mathrm{ha}$ ), $50 \%$ recommended rate (urea $75 \mathrm{~kg} / \mathrm{ha}$, SP-36 $75 \mathrm{~kg} / \mathrm{ha}$, and $\mathrm{KCl} 50$ $\mathrm{kg} / \mathrm{ha}$ ), $75 \%$ recommended rate (urea $112.5 \mathrm{~kg} / \mathrm{ha}$, SP-36 $112.5 \mathrm{~kg} / \mathrm{ha}$, and $\mathrm{KCl} 75 \mathrm{~kg} / \mathrm{ha}$ ), and $100 \%$ recommended rate (urea $150 \mathrm{~kg} / \mathrm{ha}, \mathrm{SP}-36150 \mathrm{~kg} / \mathrm{ha}$, and $\mathrm{KCl} 100 \mathrm{~kg} / \mathrm{ha}$ ).

Results showed that plants given biofertilizer by $100 \%$ recommended rate had significantly higher height, number of leaves, and fresh and dry root weight in 5 weeks after planting (WAP). Synthetic fertilizer administration by $100 \%$ recommended rate gave significantly higher plant height, number of branches, number of leaves, and fresh and dry root weight in 5 weeks after planting (WAP). Interaction of $100 \%$ recommended rate of biofertilizer and $100 \%$ recommended rate of synthetic fertilizer resulted in significantly higher number of leaves and number of flowers.

Keywords: edamame plant. Biofertilizer, synthetic fertilizer 


\section{Latar belakang}

Kedelai banyak digemari oleh masyarakat baik dalam bentuk olahan seperti tahu, tempe, susu, dan kecap atau dalam bentuk segar (direbus). Kedelai yang dimanfaatkan dalam bentuk segar adalah "edamame" (Yulianti 2013). Edamame memiliki kandungan phytic acid yang lebih tinggi dibandingkan kedelai biasa sehingga memiliki tekstur lebih halus dan lebih mudah untuk dimasak.

Menurut Kartahadimaja (2010), dosis anjuran pupuk sintetik untuk edamame adalah SP-36 sebesar $250 \mathrm{~kg} / \mathrm{ha}$, Urea $200 \mathrm{~kg} / \mathrm{ha}$, dan $\mathrm{KCl} 75 \mathrm{~kg} / \mathrm{ha}$. Namun penggunaan pupuk sintetik secara berlebih memberikan dampak buruk dalam jangka panjang. Oleh karena itu, penggunaan pupuk sintetik perlu dikurangi yaitu dengan penambahan pupuk alami. Pupuk alami dibedakan menjadi pupuk organik dan pupuk hayati.

Pupuk hayati mengandung mikroorganisme hidup, diantaranya mikroba penambat N2, pelarut fosfat, selulotik, dan sebagainya yang diberikan pada benih, tanah, atau areal pengomposan untuk meningkatkan jumlah dan aktivitas mikroorganisme (Zulkarnain 2006). Berbagai pupuk hayati yang beredar di pasaran baik dalam bentuk cair maupun granul antara lain Ultramic, Bio Extrim, MiG- $6^{\text {PLUS }}$, Biokom dan Herbafarm (Nugrahani 2012).

Pada penelitian ini pupuk hayati yang digunakan pupuk hayati majemuk cair yang diproduksi menggunakan tekhnologi nano. Dengan mengaplikasikan pupuk tersebut diharapkan dapat mengurangi penggunaan pupuk kimia sintetik.

\section{Tujuan penelitian}

Penelitian ini bertujuan untuk mengetahui pengaruh dosis pupuk hayati majemuk cair dan dosis pupuk buatan $\mathrm{N}, \mathrm{P}$ dan $\mathrm{K}$ yang optimum untuk pertumbuhan edamame.

\section{Hipotesis}

1. Dosis pupuk hayati majemuk cair berpengaruh terhadap pertumbuhan dan produksi edamame.
2. Dosis pupuk buatan N, P dan K berpengaruh terhadap pertumbuhan dan produksi edamame.

3. Terdapat interaksi antara dosis pupuk hayati dan pupuk buatan $\mathrm{N}, \mathrm{P}$ dan $\mathrm{K}$ terhadap pertumbuhan dan produksi edamame.

\section{BAHAN DAN METODE}

\section{Waktu dan Tempat}

Penelitian ini akan dilaksanakan pada bulan Febuari sampai April 2015, bertempat di Kebun Percobaan Program Studi Agroteknologi Universitas Djuanda Bogor.

\section{Alat dan Bahan}

Alat yang digunakan adalah alat tanam, instalasi irigasi, sedangkan bahan yang digunakan adalah benih edamame, pupuk buatan urea, SP 36 dan $\mathrm{KCl}$, pupuk hayati majemuk cair, dan polibag.

\section{Metode Penelitian}

Metode yang digunakan dalam penelitian ini adalah Rancangan Acak Lengkap (RAL) dengan dua faktor yaitu pupuk hayati dan pupuk sintetik. Pupuk hayati yang diberikan terdiri atas tiga taraf yaitu tanpa pupuk hayati $(0 \% \mathrm{R}), 5 \mathrm{ml} / \mathrm{l}$ (50\%R), $10 \mathrm{ml} / \mathrm{l}$ (100\%R). Pupuk sintetik yang diberikan terdiri atas lima taraf yaitu tanpa pupuk buatan $(0 \% \mathrm{R})$, pupuk sintetik $25 \%$ dari rekomendasi (Urea $37,5 \mathrm{~kg} / \mathrm{ha}$, SP$3637,5 \mathrm{~kg} / \mathrm{ha}, \mathrm{KCl} 25 \mathrm{~kg} / \mathrm{ha}$ ), pupuk sintetik $50 \%$ dari rekomendasi (Urea $75 \mathrm{~kg} / \mathrm{ha}, \mathrm{SP}-36$ $75 \mathrm{~kg} / \mathrm{ha}, \mathrm{KCl} 50 \mathrm{~kg} / \mathrm{ha}$ ), pupuk sinetik $75 \%$ dari rekomendasi (Urea 112,5 kg/ha, SP-36 $112,5 \mathrm{~kg} / \mathrm{ha}, \mathrm{KCl} 75 \mathrm{~kg} / \mathrm{ha}$ ), dan pupuk sintetik $100 \%$ dari rekomendasi (Urea 150 $\mathrm{kg} / \mathrm{ha}, \quad \mathrm{SP}-36150 \mathrm{~kg} / \mathrm{ha}, \mathrm{KCl} 100 \mathrm{~kg} / \mathrm{ha}$ ) (Departemen Pertanian 2012)

Model statistik percobaan faktorial dengan RAL adalah sebagai berikut:

$$
Y_{i j k}=\mu+\alpha_{i}+\beta_{j}+(\alpha \beta)_{i j}+\epsilon_{i j k}
$$


Keterangan:

$\mathrm{Y}_{\mathrm{ijk}}=$ Respon tanaman yang diamati (edamame) pada taraf dosis pupuk hayati ke-i dan dosis pupuk sintetik ke-j, ulangan ke-k.

$\mu \quad=$ Nilai tengah umum

$\alpha_{\mathrm{I}} \quad=$ Pengaruh dari taraf ke-i dosis pupuk hayati

$\beta_{\mathrm{j}} \quad=$ Pengaruh dari taraf ke-j dosis pupuk sintetik

$(\alpha \beta)_{\mathrm{ij}}=$ Pengaruh interaksi taraf ke-i dari faktor dosis pupuk hayati dan taraf ke-j faktor dosis pupuk sintetik.

$\boldsymbol{\epsilon}_{\mathrm{ijk}}=$ Pengaruh galat ulangan ke-k yang mendapat kombinasi perlakuan taraf ke-i dan taraf ke-j

\section{Pelaksanaan Penelitian}

Penelitian ini menggunakan media tanam berupa $8 \mathrm{~kg}$ tanah kering yang diambil dari lahan percobaan Fakultas Pertanian Universitas Djuanda Bogor yang ditambahkan pupuk hayati dan pupuk sintetik sesuai perlakuan.

Benih tanaman edamame ditanam sebanyak tiga benih per polibag, dengan jarak tanam antar polibag $25 \times 25 \mathrm{~cm}$. Pemupukan kedua dilakukan pada 2 MST. Penjarangan dilakukan pada umur 2 MST, dengan menyisakan satu tanaman per polibag. Pemeliharaan yang dilakukan meliputi kegiatan penyiraman yang dilakuan setiap hari bila tidak hujan, penyiangan yang dilakukan dua minggu sekali, dan pengendalian hama penyakit yang dilakukan pada minggu kedua dan seminggu sekali bila terjadi serangan hama penyakit yang mencolok. Pemanenan diilakukan pada umur 8 MST.

\section{Peubah yang diamati}

a. Tinggi tanaman, diukur dari leher akar hingga titik tumbuh tertinggi. Pengukuran dilakukan setiap minggu, dimulai dari umur 2 MST sampai dengan 5 MST

b. Jumlah daun, dihitung mulai dari 2 MST sampai dengan 5 MST

c. Jumlah bunga, dimulai saat tanaman mulai berbunga sampai tidak bertambah lagi jumlah bunganya. d. Jumlah cabang, dilakukan pada umur 8 MST.

e. Jumlah polong total, dihitung pada saat panen.

f. Bobot basah dan bobot kering polong, dihitung pada saat panen.

g. Persentase polong isi, dihitung pada saat panen. Rumus yang digunakan adalah:

$$
\text { PPI }=\frac{\text { Jumlah Polong Isi }}{\text { Jumlah Polong yang dihasilkan }}
$$

h. Bobot basah dan bobot kering akar, dihitung pada saat panen.

i. Jumlah bintil akar, dihitung saat panen.

\section{HASIL DAN PEMBAHASAN}

\section{Keadaan Umum}

Penanaman edamame dilakukan di Kebun Percobaan Universitas Djuanda, Bogor yang terletak pada ketinggian $400 \mathrm{~m}$ di atas permukaan laut. Lahan yang digunakan merupakan bekas pertanaman kacang panjang dan berdekatan dengan pertanaman jeruk. Benih yang ditanam mempunyai vitabilitas yang baik ditunjukan dengan perkecambahan dan pertumbuhan yang serentak.

Hama yang menyerang selama penelitian adalah ulat grayak (Spodoptera litura), ulat pemakan daun (Phaedonia inclusa Stal), ulat jengkal (Chrysodeixis chalsites), kepik polong (Riptortus linearis), belalang kayu (Valanga nigricornis), dan lalat (Ophiomyia phaseoli Tyron). Pengendalian hama yang dilakukan adalah dengan cara manual yaitu dengan pengambilan ulat dan pembersihan gulma di sekitar area penanaman. Ketika hama yang menyerang sudah dianggap membahayakan dilakukan penyemprotan menggunakan insektisida Decis bahan aktif Deltametrhin $1 \mathrm{ml} /$ liter air. Pada area pertanaman juga ditemukan penyakit seperti karat daun dan kerdil, namun intensitas sangat rendah. Pengendalian penyakit yang dilakukan dengan pencabutan pada tanaman terserang.

Pengamatan pertumbuhan vegetatif tanaman dilahan dimulai saat 2 minggu setelah tanam hingga 5 MST. Pada 30 HST mulai berbungan dan memasuki keadaan 
generatif. Hal tersebut sesuai dengan deskripsi varietas (Balitkabi, 2008).

\section{Hasil}

\section{Tinggi Tanaman}

Tabel 1 Tinggi tanaman edamame umur 2-5 MST pada berbagai dosis pupuk hayati dan pupuk sintetik

\begin{tabular}{lcccc}
\hline \multirow{2}{*}{ Perlakuan } & \multicolumn{5}{c}{ Tinggi Tanaman $(\mathrm{cm})$} \\
\cline { 2 - 5 } & $2 \mathrm{MST}$ & $3 \mathrm{MST}$ & $4 \mathrm{MST}$ & $5 \mathrm{MST}$ \\
\hline Pupuk hayati & & & & \\
$0 \% \mathrm{R}$ & 20.50 & 28.03 & 38.30 & $46.03^{\mathrm{a}}$ \\
$50 \% \mathrm{R}$ & 20.40 & 29.33 & 39.27 & $47.67^{\mathrm{b}}$ \\
$100 \% \mathrm{R}$ & 21.63 & 30.37 & 40.47 & $49.53^{\mathrm{c}}$ \\
\hline Pupuk sintetik & & & \\
$0 \% \mathrm{R}$ & $18.50^{\mathrm{a}}$ & 26.17 & $35.39^{\mathrm{a}}$ & $42.44^{\mathrm{a}}$ \\
25\% R & $22.67^{\mathrm{c}}$ & 30.83 & $39.22^{\mathrm{b}}$ & $46.67^{\mathrm{b}}$ \\
$50 \% \mathrm{R}$ & $22.11^{\mathrm{c}}$ & 30.50 & $40.22^{\mathrm{bc}}$ & $49.33^{\mathrm{c}}$ \\
$75 \% \mathrm{R}$ & $20.44^{\mathrm{b}}$ & 29.33 & $40.83^{\mathrm{bc}}$ & $49.11^{\mathrm{c}}$ \\
$100 \% \mathrm{R}$ & $20.50^{\mathrm{b}}$ & 29.39 & $41.06^{\mathrm{c}}$ & $51.17^{\mathrm{d}}$ \\
\hline
\end{tabular}

Keterangan: Nilai rata-rata pada kolom yang sama diikuti huruf yang sama tidak berbeda nyata menurut uji BNT pada taraf 5\%

Tinggi tanaman edamame dipengaruhi oleh perlakuan dosis pupuk hayati pada 5 MST dan dosis pupuk sintetik pada 2 MST, 4MST, dan 5 MST, namun tidak dipengaruhi oleh interaksi antar kedua faktor tersebut.

Pada umur 2, 4, dan 5 MST, tanaman yang diberikan pupuk sintetik dengan dosis $25 \%, 50 \%, 75 \%$, dan $100 \%$ rekomendasi lebih tinggi dibandingkan dengan tanaman yang tidak diberikan pupuk.

\section{Jumlah Daun}

Jumlah daun tanaman edamame pada umur 2-5 MST nyata dipengaruhi oleh dosis pupuk hayati, dosis pupuk sintetik, dan interaksi antar keduanya terdapat pada 2 MST.

Pada 3 MST, tanaman dengan dosis pupuk sintetik $25 \%$ rekomendasi memiliki jumlah daun lebih banyak dibandingkan dengan tanpa pupuk sintetik, 50\% rekomendasi, dan $100 \%$ rekomendasi namun tidak berbeda nyata dengan dosis $75 \%$ rekomendasi (Tabel 2).

Tabel 2 Jumlah daun edamame umur 2-5 MST pada berbagai dosis pupuk hayati dan pupuk sintetik

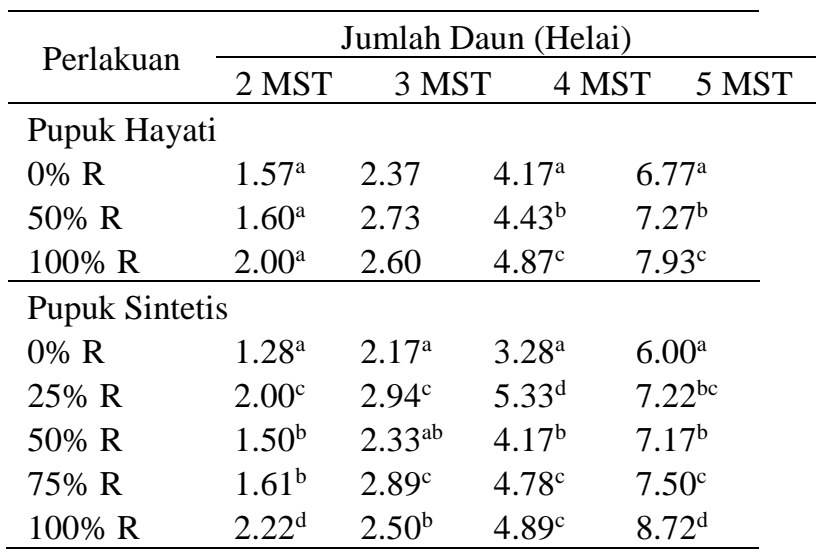

Keterangan: Nilai rata-rata pada kolom yang sama diikuti huruf yang sama tidak berbeda nyata menurut uji BNT pada taraf $5 \%$

Pada umur 4 MST, tanaman dengan dosis pupuk hayati $100 \%$ rekomendasi dan dosis pupuk sintetik 25\% rekomendasi memiliki jumlah daun lebih banyak dibanding dosis lainnya. Pada 5 MST, tanaman dengan dosis pupuk hayati $100 \%$ rekomendasi dan dosis pupuk sintetik $100 \%$ rekomendasi memiliki jumlah daun yang lebih banyak dibandingkan dosis pupuk hayati dan sintetik lainnya (Tabel 2).

Pemberian dosis pupuk sintetik dan pupuk hayati $100 \%$ rekomendasi menghasilkan jumlah daun yang nyata lebih banyak dibandingkan dengan pemberian dosis pupuk hayati dan pupuk sintetik lainnya. Tanaman yang diberi pupuk hayati $0 \%$ rekomendasi, pupuk sintetik $25 \%$ rekomendasi memiliki jumlah daun lebih banyak dibandingkan dengan dosis $0 \%, 50 \%$ $75 \%$, dan $100 \%$ rekomendasi (Tabel 3). 
Tabel 3 Jumlah daun edamame pada kombinasi dosis pupuk hayati dan dosis pupuk sintetik

\begin{tabular}{clllll}
\hline Perlakuan & \multicolumn{5}{c}{ Pupuk Sintetik } \\
\hline Pupuk Hayati & $0 \% \mathrm{R}$ & \multicolumn{1}{c}{$25 \% \mathrm{R}$} & $50 \% \mathrm{R}$ & $75 \% \mathrm{R}$ & $100 \% \mathrm{R}$ \\
\hline $0 \% \mathrm{R}$ & $1.00^{\mathrm{a}}$ & $2.17^{\mathrm{ef}}$ & $2.00^{\text {cdef }}$ & $1.33^{\text {abcd }}$ & $1.33^{\text {abcd }}$ \\
$50 \% \mathrm{R}$ & $1.50^{\text {abcde }}$ & $1.50^{\text {abcde }}$ & $1.17^{\mathrm{ab}}$ & $1.83^{\text {bcdef }}$ & $2.00^{\text {def }}$ \\
$100 \% \mathrm{R}$ & $1.33^{\text {abcd }}$ & $2.33^{\mathrm{f}}$ & $1.33^{\mathrm{abcd}}$ & $1.67^{\mathrm{abcdef}}$ & $3.33^{\mathrm{g}}$ \\
\hline
\end{tabular}

Keterangan: Nilai rata-rata pada kolom yang sama diikuti huruf yang sama tidak berbeda nyata menurut uji BNT pada taraf 5\%

\section{Jumlah Bunga}

Jumlah bunga tanaman edamame nyata dipengaruhi oleh dosis pupuk sintetik dan interaksi antara keduanya. Jumlah bunga pada dosis pupuk sintetik dengan $100 \%$ rekomendasi nyata lebih banyak dibandingkan dengan dosis pupuk sintetik lainnya dan yang diberikan pupuk 25\%, 50\%, dan $75 \%$ rekomendasi nyata lebih banyak dibandingkan $0 \%$ rekomendasi (Tabel 4).

Tabel 4 Jumlah bunga edamame umur 30-42 HST pada berbagai dosis pupuk hayati dan pupuk sintetik

\begin{tabular}{lcccc}
\hline \multicolumn{1}{c}{ Perlakuan } & \multicolumn{4}{c}{ Jumlah Bunga (Kuntum) } \\
& 30 HST & 32 HST & 35 HST & $42 \mathrm{HST}$ \\
\hline Pupuk Hayati & & & \\
0\% R & 10,73 & 13,77 & 17,27 & 24,70 \\
$50 \% \mathrm{R}$ & 11,00 & 14,43 & 17,73 & 25,60 \\
$100 \% \mathrm{R}$ & 10,10 & 13,43 & 16,77 & 25,03 \\
\hline Pupuk Sintetik & & & \\
$0 \% \mathrm{R}$ & $8,94^{\mathrm{a}}$ & $12,44^{\mathrm{a}}$ & $15,11^{\mathrm{a}}$ & $21,22^{\mathrm{a}}$ \\
$25 \% \mathrm{R}$ & $10,78^{\mathrm{bc}}$ & $14,28^{\mathrm{cd}}$ & $17,72^{\mathrm{bc}}$ & $24, \mathrm{~d}^{\mathrm{c}}$ \\
$50 \% \mathrm{R}$ & $10,33^{\mathrm{bc}}$ & $13,44^{\mathrm{b}}$ & $18,00^{\mathrm{bc}}$ & $23,39^{\mathrm{b}}$ \\
$75 \% \mathrm{R}$ & $11,28^{\mathrm{cd}}$ & $14,11^{\mathrm{c}}$ & $17,17^{\mathrm{b}}$ & $25,67^{\mathrm{d}}$ \\
$100 \% \mathrm{R}$ & $11,72^{\mathrm{d}}$ & $15,11^{\mathrm{e}}$ & $18,28^{\mathrm{c}}$ & $30,72^{\mathrm{e}}$ \\
\hline Keterangan: Nilai rata-rata pada kolom yang sama diikuti huruf yang sama tidak berbeda nyata \\
\multicolumn{4}{c}{}
\end{tabular}

Pada dosis pupuk hayati $100 \%$ rekomendasi, pemberian dosis pupuk sintetik $100 \%$ rekomendasi menghasilkan jumlah bunga yang nyata lebih banyak dibandingkan dengan pemberian dosis pupuk hayati dan pupuk sintetik lainnya (Tabel 5).

Tabel 5 Jumlah bunga edamame pada kombinasi dosis pupuk hayati dan dosis pupuk sintetik

\begin{tabular}{crrrrr}
\hline Perlakuan & \multicolumn{5}{c}{ Pupuk Sintetik } \\
\hline Pupuk Hayati & $0 \% \mathrm{R}$ & $25 \% \mathrm{R}$ & \multicolumn{1}{c}{$50 \% \mathrm{R}$} & \multicolumn{1}{c}{$75 \% \mathrm{R}$} & $100 \% \mathrm{R}$ \\
\hline $0 \% \mathrm{R}$ & $22,67^{\text {bcd }}$ & $23,17^{\text {bcde }}$ & $25,00^{\text {defgh }}$ & $24,00^{\text {bcdefg }}$ & $28,76^{\text {jk }}$ \\
$50 \% \mathrm{R}$ & $21,33^{\text {ab }}$ & $25,00^{\text {defgh }}$ & $23,50^{\text {bcdef }}$ & $27,50^{\text {hij }}$ & $30,67^{\mathrm{kl}}$ \\
$100 \% \mathrm{R}$ & $19,67^{\mathrm{a}}$ & $25,50^{\text {efghi }}$ & $21,67^{\text {abc }}$ & $25,50^{\text {efghi }}$ & $32,83^{1}$ \\
\hline
\end{tabular}

Keterangan: Nilai rata-rata pada kolom yang sama diikuti huruf yang sama tidak berbeda nyata menurut uji BNT pada taraf $5 \%$ 


\section{Jumlah Polong}

Jumlah polong tidak dipengaruhi baik oleh dosis pupuk hayati, dosis pupuk sintetik, maupun interaksi antara keduanya. Jumlah polong tidak berbeda nyata antar perlakuan (Tabel 6).

\section{Bobot Basah Polong}

Bobot basah polong tidak dipengaruhi baik oleh dosis pupuk hayati, dosis pupuk sintetik, maupun interaksi antara keduanya. Bobot basah polong tidak berbeda nyata antar perlakuan (Tabel 6).

Tabel 6 Jumlah, bobot basah, dan bobot kering polong edamame umur pada berbagai dosisi pupuk hyati dan pupuk sintetik.

\begin{tabular}{lcccc}
\hline Perlakuan & $\begin{array}{c}\text { Jumlah } \\
\text { Polong } \\
\text { (bh) }\end{array}$ & $\begin{array}{c}\text { Bobot } \\
\text { Basah } \\
\text { Polong } \\
(\mathrm{g})\end{array}$ & $\begin{array}{c}\text { Bobot } \\
\text { Kering } \\
\text { Polong } \\
(\mathrm{g})\end{array}$ & $\begin{array}{c}\text { Persentase } \\
\text { Polong Isi } \\
(\%)\end{array}$ \\
\cline { 1 - 4 } Pupuk Hayati & & & \\
0\% R & 37.77 & 77.27 & 21.43 & 89,93 \\
50\% R & 40.60 & 70.87 & 17.19 & 89,88 \\
100\% R & 119.57 & 75.17 & 18.12 & 90,09 \\
\hline Pupuk Sintetik & & & \\
0\% R & 39.50 & 78.28 & 20.23 & 90,75 \\
25\% R & 43.89 & 70.61 & 15.43 & 90,80 \\
50\% R & 34.17 & 71.67 & 18.66 & 88,08 \\
$75 \%$ R & 39.44 & 70.33 & 17.04 & 90,26 \\
100\% R & 42.28 & 81.28 & 23.19 & 89,95 \\
\hline
\end{tabular}

\section{Bobot Kering Polong}

Bobot kering polong tidak dipengaruhi baik oleh dosis pupuk hayati, dosis pupuk sintetik, maupun interaksi antara keduanya. Bobot kering polong tidak berbeda nyata antar perlakuan (Tabel 6).

\section{Persentase Polong Isi}

Bobot kering polong tidak dipengaruhi baik oleh dosis pupuk hayati, dosis pupuk sintetik, maupun interaksi antara keduanya. Bobot kering polong tidak berbeda nyata antar perlakuan (Tabel 6).

\section{Jumlah Bintil}

Jumlah bintil tidak dipengaruhi baik oleh dosis pupuk hayati, dosis pupuk sintetik, maupun interaksi antara keduanya. Jumlah bintil tidak berbeda nyata antar perlakuan (Tabel 7).

Tabel 7 Jumlah bintil tanaman edamame pada berbagai dosis pupuk hayati dan pupuk sintetik

\begin{tabular}{lc}
\hline \multicolumn{1}{c}{ Perlakuan } & Jumlah Bintil (Bh) \\
\hline Pupuk Hayati & \\
0\% R & 7.50 \\
$50 \% \mathrm{R}$ & 5.60 \\
$100 \% \mathrm{R}$ & 8.00 \\
\hline Pupuk Sintetik & \\
$0 \% \mathrm{R}$ & 5.89 \\
$25 \% \mathrm{R}$ & 5.94 \\
$50 \% \mathrm{R}$ & 5.11 \\
$75 \% \mathrm{R}$ & 7.28 \\
$100 \% \mathrm{R}$ & 10.94 \\
\hline
\end{tabular}

Keterangan: Nilai rata-rata pada kolom yang sama diikuti huruf yang sama tidak berbeda nyata menurut uji BNT pada taraf 5\%

\section{Jumlah Cabang}

Tabel 8 Jumlah cabang edamame pada berbagai dosis pupuk hayati dan pupuk sintetik

\begin{tabular}{ll}
\hline Perlakuan & Jumlah Cabang (Bh) \\
\hline Pupuk Hayati & \\
$0 \% \mathrm{R}$ & 3,63 \\
$50 \% \mathrm{R}$ & 3,87 \\
$100 \% \mathrm{R}$ & 3,57 \\
\hline Pupuk Sintetik & \\
$0 \% \mathrm{R}$ & $3,33^{\text {ab }}$ \\
$25 \% \mathrm{R}$ & $3,22^{\mathrm{a}}$ \\
$50 \% \mathrm{R}$ & $3,67^{\mathrm{c}}$ \\
$75 \% \mathrm{R}$ & $3,89^{\mathrm{cd}}$ \\
$100 \% \mathrm{R}$ & $4,33^{\mathrm{e}}$ \\
\hline
\end{tabular}

Keterangan: Nilai rata-rata pada kolom yang sama diikuti huruf yang sama tidak berbeda nyata menurut uji BNT pada taraf 5\%

\section{Panjang Akar}

Panjang akar tidak dipengaruhi baik oleh dosis pupuk hayati, dosis pupuk sintetik, maupun interaksi antara keduanya. Panjang akar tidak berbeda nyata antar perlakuan (Tabel 9). 


\section{Bobot Basah Akar}

Bobot basah akar nyata dipengaruhi baik oleh dosis pupuk hayati, dosis pupuk sintetik, namun tidak dipengaruhi oleh interaksi antar kedua faktor tersebut (Tabel 9).Bobot basah akar tanaman edamame pada dosis pupuk hayati dan pupuk sintetik dengan $100 \%$ rekomendasi nyata lebih tinggi dibandingkan dengan tanaman yang diberi pupuk hayati dan sintetik dengan dosis lainnya (Tabel 9).

Tabel 9 Panjang, bobot basah, dan bobot kering akar tanaman edamame pada berbagai dosis pupuk hayati dan pupuk sintetik.

\begin{tabular}{lccl}
\hline Perlakuan & $\begin{array}{c}\text { Panjang } \\
\text { Akar }(\mathrm{cm})\end{array}$ & $\begin{array}{c}\text { Bobot Basah } \\
\text { Akar }(\mathrm{g})\end{array}$ & $\begin{array}{c}\text { Bobot Kering } \\
\text { Akar }(\mathrm{g})\end{array}$ \\
\hline $\begin{array}{l}\text { Pupuk } \\
\text { Hayati }\end{array}$ & & & \\
$0 \% \mathrm{R}$ & 47.03 & $8,70^{\mathrm{a}}$ & $3,14^{\mathrm{a}}$ \\
$50 \% \mathrm{R}$ & 46.37 & $9,54^{\mathrm{b}}$ & $3,56^{\mathrm{b}}$ \\
$100 \% \mathrm{R}$ & 45.50 & $10,14^{\mathrm{b}}$ & $3,68^{\mathrm{c}}$ \\
\hline Pupuk & & & \\
Sintetik & & & \\
$0 \% \mathrm{R}$ & 44.72 & $8,94^{\mathrm{a}}$ & $3,14^{\mathrm{a}}$ \\
$25 \% \mathrm{R}$ & 48.33 & $9,25^{\mathrm{b}}$ & $3,22^{\mathrm{ab}}$ \\
$50 \% \mathrm{R}$ & 44.00 & $9,28^{\mathrm{bc}}$ & $3,25^{\mathrm{bc}}$ \\
$75 \% \mathrm{R}$ & 47.61 & $9,48^{\mathrm{bcd}}$ & $3,67^{\mathrm{d}}$ \\
$100 \% \mathrm{R}$ & 46.83 & $10,35^{\mathrm{e}}$ & $4,03^{\mathrm{e}}$ \\
\hline Ket
\end{tabular}

Keterangan: Nilai rata-rata pada kolom yang sama diikuti huruf yang sama tidak berbeda nyata menurut uji BNT pada taraf 5\%.

\section{Bobot Kering Akar}

Bobot kering akar nyata dipengaruhi baik oleh dosis pupuk hayati, dosis pupuk sintetik, namun tidak dipengaruhi oleh interaksi antar kedua faktor tersebut. Bobot kering akar tanaman edamame pada dosis pupuk hayati dan pupuk sintetik dengan $100 \%$ rekomendasi nyata lebih tinggi dibandingkan dengan tanaman yang diberi pupuk hayati dan sintetik dengan dosis lainnya (Tabel 9).

\subsection{Pembahasan}

\subsubsection{Pengaruh Pupuk Hayati terhadap Tanaman Tanaman edamame}

Pemberian pupuk hayati pada penelitian ini nyata mempengaruhi pertumbuhan tinggi tanaman, jumlah daun, bobot basah dan kering akar. Hal ini diduga karena ketersediaan unsur hara merupakan salah satu faktor lingkungan yang sangat menentukan laju pertumbuhan tanaman (Gardner et al. 1985). Kebutuhan unsur hara esensial dapat diperoleh melalui dosis pupuk hayati yang didalamnya mengandung salah satu mikroorganisme (Nugrahani et al 2012).

Pemberian pupuk hayati merupakan upaya memperbaiki kondisi lingkungan tanaman dalam hal penyediaan unsur hara, menetralkan $\mathrm{pH}$ tanah dan mengaktifkan zat renik maupun mikroorganisme dalam tanah, sehingga tanah menjadi gembur dan subur. Pupuk hayati adalah inokulan aktif organisme hidup yang berfungsi untuk menambat hara tertentu atau menfasilitasi tersedianya hara bagi tanaman (Simanungkalit et al 2006).

Pupuk hayati yang diberikan kedalam tanah akan mengakibatkan perubahan sifat biologi dan kimia tanah. Nurshanti (2009) menerangkan, kelembaban tanah yang baik akan meningkatkan metabolisme tanaman yang diikuti dengan meningkatnya pertumbuhan tanaman. Hal ini disebabkan karena proses penyerapan zat hara dapat berlangsung baik. Pada kelembaban tanah yang baik akar akan lebih mudah menyerap nitrogen dan posfat.

Menurut Rachmawati et al (2016), pemberian pupuk hayati dapat memberikan pertumbuhan yang baik terhadap tinggi tanaman, jumlah daun, lebar tajuk, panjang akar, dan bobot per tanaman. Menurut Husein (2005), pupuk hayati dapat meningkatkan tinggi tanaman dan bobot akar.

\subsubsection{Pengaruh Pupuk Sintetik terhadap Tanaman Tanaman edamame}

Pemberian pupuk sintetik berpengaruh terhadap tinggi tanaman, jumlah cabang, jumlah daun, jumlah bunga, bobot kering akar dan bobot basah akar. Pupuk sintetik secara 
umum mampu memperbaiki sifat kimia tanah. Dengan kondisi tanah yang baik akan menciptakan lingkungan tumbuh yang sesuai bagi pertumbuhan tanaman, yaitu tercermin pada penampilan tanaman yang berupa tinggi, jumlah daun, dan bobot tanaman yang baik (Kresnatita et al 2013).

Tanaman edamame yang tidak diberikan pupuk sintetik menunjukan hasil yang paling rendah. Hal ini menunjukan bahwa tanaman edamame merupakan tanaman yang memerlukan unsur hara, khususnya Nitrogen $(\mathrm{N})$ dalam jumlah yang cukup selama pertumbuhannya. Dengan pemupukan $\mathrm{N}$ yang cukup, maka pertumbuhan organ-organ tanaman akan sempurna dan fotosintat akan meningkat, yang pada akhirnya mendukung produksi tanaman (Kresnatita et al 2013). Nitrogen (N) yang terkandung dalam pupuk sintetik berpengaruh pada tinggi tanaman dan bobot akar (Gardner et al 1991).

Peningkatan karakter vegetatif seperti tinggi tanaman, jumlah daun, dan jumlah cabang disebabkan oleh peranan dari unsur nitrogen. Peran utama nitrogen bagi tumbuhan adalah untuk merangsang pertumbuhan secara keseluruhan, khususnya batang, cabang dan daun (Lingga 2007).

Pemupukan fosfor berperan mempercepat pertumbuhan akar, mempercepat pertumbuhan tanaman muda menjadi tanaman dewasa, mempercepat pembungaan dan pemasakan buah dan biji dan meningkatkan produksi biji-bijian (Sutedjo 2002). Selain pemupukan nitrogen dan fosfor pada penelitian ini, pemupukan kalium yang diberikan berpengaruh mengatur tekanan turgor sel yang berperan dalam proses membuka dan menutupnya stomata (Lakitan 2007).

\subsubsection{Interaksi Pupuk Hayati dengan Pupuk Sintetik terhadap Tanaman Tanaman edamame}

Interaksi antara pupuk hayati dengan pupuk sintetik berpengaruh nyata terhadap jumlah daun dan jumlah bunga. Kombinasi antara dosis pupuk hayati dan pupuk sintetik dengan $100 \%$ rekomendasi memberikan hasil tertinggi pada jumlah daun dan jumlah bunga.

\section{KESIMPULAN DAN SARAN}

\section{Kesimpulan}

Berdasarkan hasil penelitian, dapat disimpulkan bahwa tanaman edamame dengan dosis pupuk hayati $100 \%$ rekomendasi memiliki tinggi tanaman, jumlah daun, bobot basah akar, dan bobot kering akar lebih tinggi dibandingkan dengan tanaman edamame yang diberi pupuk hayati dengan dosis $0 \%$ dan $50 \%$ rekomendasi. Tanaman edamame dengan dosis pupuk sintetik $100 \%$ rekomendasi memiliki tinggi tanaman, jumlah daun, jumlah bunga, jumlah cabang, bobot basah akar, dan bobot kering akar yang lebih tinggi dibandingkan dengan tanaman edamame yang diberi pupuk sintetik dengan dosis $0 \%, 25,50 \%$, dan $75 \%$ rekomendasi.

Tanaman edamame dengan kombinasi perlakuan pupuk hayati dan pupuk sintetik dengan dosis $100 \%$ rekomendasi menghasilkan jumlah daun dan jumlah bunga lebih tinggi dibandingkan dengan perlakuan lainnya.

\section{Saran}

Perlu dilakukan penelitian lebih lanjut mengenai pengaruh pemberian berbagai dosis pupuk hayati dan pupuk sintetik terhadap pertumbuhan dan produksi tanaman edamame.

\section{DAFTAR PUSTAKA}

Gardner FP, Pearce RP, Mitchell RL. 1991. Fisiologi Tanaman Budidaya. Terjemahan: Herawati Susilo. UI Press: Jakarta.

Husein U. 2005. Metode Penelitian. Jakarta: Salemba Empat.

Kartahadimaja J, Wentasari R, Sesanti RN. 2010. Pertumuhan dan Produksi Polong Segar Edamame Varietas Rioko pada Empat Jenis Pupuk. Agrovigor 3(2): 131-136.

Kresnatita S, Koesriharti, Santoso M. 2013. Pengaruh Rabuk Oganik terhadapp Pertumbuhan dan Hasil Jagung Manis. [Jurnal] Indonesia Green Technology Journal 2(1): 8-17. 
Lakitan B. 2007. Dasa-Dasar Fisiologi Tumbuhan. Raja Grrafindo Persada: Jakarta.

Lingga P, Marsono. 2007. Petunjuk Penggunaan Pupuk. Edisi Revisi. Penebar Swadaya: Jakarta.

Nugrahani O, Suprihati A, Yohanes H. 2012. Pengaruh Pupuk Hayati Terhadap Pertumbuhan dan Hasil Tanaman Sawi Sendok (Brasicca juncea (L.) (Zern)) denga Budidaya Ramah Lingkungan. Agric 24(1): 29-34.

Nurshanti FD. 2009. Pengaruh Pemberian Pupuk Hayati terhadap Pertumbuhan dan Hasil Tanaman Sawi Caisin (Brassica junicea L.). [Jurnal] Agronobis, 1(1): 89-98.

Rachawati D, Korlina E. 2016. Kajian Penggunaan Pupuk Hayati untuk Mengendalikan Penyakit Akar Gada (Plasmodiophora brasiccae) pada Tanaman Sawi Daging. [Jurnal] Agrivogor 9(1): 67-72.
Simanungkalit, R.D.M., R. Saraswati, R.D. Hastuti, dan E. Husen. 2006. Bakteri Penambat Nitrogen. Hlm 113-140 Dalam R.D.M. (Eds.). Pupuk Organik dan Pupuk Hayati.Balai Besar Litbang Sumberdaya Lahan Pertanian.

Bogor.

Sutedjo MM. 2002. Pupuk dan Cara Pemupukan. Rineka Cipta: Jakarta.

Yulianti N. 2013. Pertumbuhan dan Produksi Tanaman edamame (Glycine max (L.) Merr.) Pada Berbagai Dosis Zeolit dan Jenis Pupuk Nitrogen [Skripsi]. Bogor: Universitas Djuanda.

Zulkarnain. 2006. Pengaruh Dosis Pupuk NPK Konsentrasi Larutan Gibberelin Acid (GA3) Terhadap Pertumbuhan Semai Akasia (Acacia mangium). Thesis Universitas Muhammadiyah Malang 